\title{
Responses of Ammonia-Oxidising Bacterial Communities to Nitrogen, Lime, and Plant Species in Upland Grassland Soil
}

\author{
Deirdre C. Rooney, ${ }^{1,2}$ Nabla M. Kennedy, ${ }^{1,3}$ Deirdre B. Gleeson, ${ }^{4}$ and Nicholas J. W. Clipson ${ }^{1}$ \\ ${ }^{1}$ Microbial Ecology Group, School of Biology and Environmental Science, University College Dublin, Belfield, Dublin 4, Ireland \\ ${ }^{2}$ Agriculture Department, Askham Bryan College, Askham Bryan, York 23 3FR, UK \\ ${ }^{3}$ Ecosystem Science and Management Program, University of Northern British Columbia, 3333 University Way, \\ Prince George, BC, Canada V2N $4 Z 9$ \\ ${ }^{4}$ Soil Biology Group, School of Earth and Environment (M087), The University of Western Australia, 35 Stirling Highway, \\ WA 6009 Crawley, Australia
}

Correspondence should be addressed to Nabla M. Kennedy, nabla.kennedy@gmail.com

Received 30 January 2010; Accepted 16 June 2010

Academic Editor: Oliver Dilly

Copyright (C) 2010 Deirdre C. Rooney et al. This is an open access article distributed under the Creative Commons Attribution License, which permits unrestricted use, distribution, and reproduction in any medium, provided the original work is properly cited.

Agricultural improvement of seminatural grasslands has been shown to result in changes to plant and microbial diversity, with consequences for ecosystem functioning. A microcosm approach was used to elucidate the effects of two key components of agricultural improvement (nitrogen addition and liming) on ammonia-oxidising bacterial (AOB) communities in an upland grassland soil. Plant species characteristic of unimproved and improved pastures (A. capillaris and L. perenne) were planted in microcosms, and lime, nitrogen $\left(\mathrm{NH}_{4} \mathrm{NO}_{3}\right)$, or lime plus nitrogen added. The AOB community was profiled using terminal restriction fragment length polymorphism (TRFLP) of the amoA gene. AOB community structure was largely altered by $\mathrm{NH}_{4} \mathrm{NO}_{3}$ addition, rather than liming, although interactions between nitrogen addition and plant species were also evident. Results indicate that nitrogen addition drives shifts in the structure of key microbial communities in upland grassland soils, and that plant species may play a significant role in determining $\mathrm{AOB}$ community structure.

\section{Introduction}

The impact of anthropogenic activities on soil biodiversity is central to our understanding of the links between soil functional diversity, species diversity, and overall ecosystem functioning. Agricultural improvement of natural upland pastures is widespread in NW Europe, with increased fertilisation, liming, and grazing producing a shift in the floristic composition of acidic upland grasslands [1,2]. Such intensification practices result in a gradual shift from a plant species-rich Agrostis capillaris pasture to a species-poor grassland dominated by Lolium perenne [3], with concurrent changes in soil physicochemical properties $[1,4,5]$, most notably soil nutrient status. Nitrogen pools in particular have been shown to be held in different ratios between unimproved and improved grasslands, with ammonium dominating unimproved pastures, while nitrate is prevalent in improved pastures [5].
Soil bacterial and fungal communities are also understood to undergo changes in response to agricultural management [4-7], so it is likely that specific functional groups, such as ammonia-oxidising bacteria (AOB), may be similarly affected. The initial step in nitrification-the conversion of ammonium to nitrite-is microbially mediated by ammonia oxidisers via the enzyme ammonia monoxygenase (AMO). In recent years, exploitation of the amoA gene as a molecular marker and the application of community fingerprinting techniques have revealed considerable $\mathrm{AOB}$ diversity [8].

While previous studies have suggested that $\mathrm{AOB}$ community structure may be affected by land management regimes [9-11], the impacts of individual components of improvement (i.e., fertiliser addition, liming, floristic composition) and their interactions on $\mathrm{AOB}$ communities in grasslands are not well defined. This study investigates the responses of $\mathrm{AOB}$ to nitrogen and lime additions in upland grassland microcosms. Previous work has indicated that the general 
rhizosphere bacterial community in acidic grasslands is impacted more by chemical treatments, particularly liming, than by plant species [6]. We hypothesise that the $\mathrm{AOB}$ community will be similarly unaffected by plant species. Due to the crucial role of $\mathrm{AOB}$ in nitrogen cycling, we expect that nitrogen manipulations will have a greater influence than liming.

\section{Materials and Methods}

Soil was collected from an area of unimproved Nardo-Galion grassland at Longhill, County Wicklow, Ireland, and used for microcosms as described previously [6]. Pots were filled with $80 \mathrm{~g}$ (dry mass) of sieved bulk soil, then planted with 2025 seeds (Emorsgate Seeds, Kings Lynn, UK) of the chosen grassland species (Agrostis capillaris or Lolium perenne), and water content was adjusted to $35 \%(\mathrm{w} / \mathrm{w})$. A set of unplanted pots was also included, and microcosms were harvested 75 days after visible germination of seeds. Both planted and unplanted pots were treated on Day 25 as follows: (1) no treatment (NT); (2) addition of lime equivalent to 5 tons ha ${ }^{-1}$ (L); (3) addition of $\mathrm{NH}_{4} \mathrm{NO}_{3}$ equivalent to $150 \mathrm{~kg} \mathrm{Nha}^{-1}(\mathrm{~N})$; and (4) addition of both lime and $\mathrm{NH}_{4} \mathrm{NO}_{3}$ as above (LN). Microcosms were destructively sampled on Day 75. Plant root and shoot material were removed, dried at $70^{\circ} \mathrm{C}$ for 7 days, and weighed. Due to the small size of the microcosms used and the high root density in pots, all soil was assumed to have been in contact with plant roots and was considered rhizosphere. Soil was sieved to $<4 \mathrm{~mm}$ and stored at $4^{\circ} \mathrm{C}$ for less than 7 days for $\mathrm{pH}$, microbial activity, and biomass analysis, and at $-20^{\circ} \mathrm{C}$ for molecular analyses. Soil $\mathrm{pH}$, nitrogen, phosphorus, and potassium were measured as described previously [6]. Total microbial activity was measured as triphenylformazan dehydrogenase activity [12] and was determined based on a modification of the method of Thalmann [13]. Total soil DNA was extracted as described by Brodie et al. [5]. Briefly, soil $(0.5 \mathrm{~g})$ was added to tubes containing glass and zirconia beads, to which CTAB (hexadecyltrimethylammonium bromide) extraction buffer was added. After incubation at $70^{\circ} \mathrm{C}$ for $10 \mathrm{~min}$, phenol: chloroform : isoamylalcohol $(25: 24: 1)$ was added and tubes were then shaken in a Hybaid Ribolyser at $5.5 \mathrm{~m} / \mathrm{s}$ for $30 \mathrm{~s}$. Following bead beating, tubes were centrifuged and the aqueous layer was removed and extracted twice with chloroform: isoamlyalcohol $(24: 1)$. A further purification procedure was performed involving incubation with lysozyme solution $(100 \mathrm{mg} / \mathrm{mL})$ for $30 \mathrm{~min}$ at $37^{\circ} \mathrm{C}$. Tubes were again centrifuged and the aqueous layer removed and further purified using a High Pure PCR Product Clean Up Kit (Roche Diagnostics GmbH, Penzberg, Germany) according to manufacturer's instructions. DNA was eluted in a final volume of $50 \mu \mathrm{L}$. Terminal restriction fragment length polymorphism (TRFLP) was carried out using the primer set $a m o-1 \mathrm{~F}$ and amo-2R $[14,15]$, with the forward primer labelled with fluorescent dye D4. PCR reactions were performed in $50 \mu \mathrm{L}$ volumes using PCR Master-Mix (Promega), $15 \mathrm{pmol}$ of each primer, and $\sim 10 \mathrm{ng}$ extracted DNA, and subsequently purified using a PCR product purification kit (Roche). Approximately $50 \mathrm{ng}$ of PCR product was digested using restriction endonuclease TaqI (NEB) according to manufacturer's instructions [15]. One microlitre of desalted digests was mixed with $38.75 \mu \mathrm{L}$ of sample loading solution and $0.25 \mu \mathrm{L}$ of Beckman Coulter size standard 600. Terminal restriction fragment lengths were determined by electrophoresis using a Beckman Coulter CEQ 8000 automated sequencer, and analysed using the Beckman Coulter fragment analysis package v 8.0. Profiles were generated for each sample based on relative heights (abundance) of peaks. Peak heights for each terminal restriction fragment (TRF) were first converted into proportions of the total peak height of all TRFs for each replicate. TRFs that differed by less than $0.5 \mathrm{bp}$ were considered identical and only fragments occurring in two or more replicates were used [16]. Each fragment was then considered a unique operational taxonomic unit (OTU).

The experimental design consisted of two factors: management type (4 levels, fixed) and plant type (3 levels, fixed) with four replicates. Data sets for soil chemistry, root and shoot biomass, and microbial activity and number of TRFs were analysed by one-way factorial analysis of variance (ANOVA) using Genstat v 6 (significance level: $P<.05)$, after being tested for normality. Multivariate statistical analyses were performed on amoA TRFLP profiles with Primer 6 package (Primer-E Ltd, UK), using standardised and transformed $(\log (X+1))$ TRFLP profiles and the Bray-Curtis similarity measure. Principal coordinate analysis (PCO) was used as an unconstrained ordination method to visualise multivariate patterns within each plant treatment. Analysis of similarity (ANOSIM) was used to investigate the effects of treatment and plant species on $\mathrm{AOB}$ community structure. ANOSIM was performed on Bray-Curtis similarity matrices. Comparisons of mean distances within treatments were used to calculate the ANOSIM $R$-statistic $(R)$, with $R=1$ indicating the populations were dissimilar, and $R=0$ indicating that populations were random. Permutational multivariate analysis of variance (PERMANOVA) was also carried out to investigate the effects of treatment and plant species on $\mathrm{AOB}$ community profiles, as this procedure can determine if interactions between treatment and plant species were significant. The SIMPER procedure (similarity percentage analysis) was used to identify those TRFs (OTUs) that characterised each treatment group (NT, L, N, LN) identified by cluster analysis [17].

\section{Results}

The soil used for these microcosms had a starting $\mathrm{pH}$ of 4.0-4.5. Results of microcosm soil physicochemical analysis are presented in Table 1 (modified from [6]). Soil pH varied significantly $(P<.005)$ with chemical treatment, most notably with a significant increase in soil $\mathrm{pH}$ after liming (to approximately a value commonly found in semi-improved grassland [5]), and a decrease in soil $\mathrm{pH}$ under $\mathrm{N}$ treatment (although more acidic than the original soil, this value was still within the normal range for an unimproved acidic grassland [5]). Addition of nitrogen typically reduces soil 
TABle 1: Soil, plant, and microbial characteristics for grassland microcosms. Nitrogen/Lime treatments, $n=12$; plant treatments, $n=16$. Different letters indicate values that are significantly different. SED, standard error of the difference. Significance levels: $*^{*} P<.01$; ${ }^{* * *} P<.001$. Parts of this table have been previously presented in the work by Kennedy et al. [6].

\begin{tabular}{|c|c|c|c|c|c|c|c|}
\hline & $\mathrm{pH}$ & $\begin{array}{l}\text { Root Biomass } \\
\text { (mg per plant) }\end{array}$ & $\begin{array}{l}\text { Shoot Biomass } \\
\text { (mg per plant) }\end{array}$ & $\begin{array}{l}\text { Microbial Activity } \\
\text { (mg TPF g }{ }^{-1} \text { soil) }\end{array}$ & $\begin{array}{c}\text { Nitrogen } \\
(\%)\end{array}$ & $\begin{array}{l}\text { Phosphorus } \\
\left(\mathrm{mg} \mathrm{P} \mathrm{kg}^{-1}\right)\end{array}$ & $\begin{array}{c}\text { Potassium } \\
\left(\mathrm{mg} \mathrm{K} \mathrm{kg}^{-1}\right)\end{array}$ \\
\hline \multicolumn{8}{|l|}{ Nitrogen/Lime treatments } \\
\hline No treatment (plant only) & $4.23 \mathrm{~b}$ & $1.90 \mathrm{a}$ & $1.94 \mathrm{a}$ & $49.2 \mathrm{~b}$ & $0.62 \mathrm{a}$ & $8.54 \mathrm{a}$ & $140.7 \mathrm{~b}$ \\
\hline Lime & $4.92 \mathrm{~d}$ & $1.64 \mathrm{a}$ & $3.68 \mathrm{c}$ & $158.0 \mathrm{~d}$ & $0.55 \mathrm{a}$ & $11.88 \mathrm{c}$ & $156.3 \mathrm{~d}$ \\
\hline $\mathrm{NH}_{4} \mathrm{NO}_{3}$ & $3.78 \mathrm{a}$ & $3.81 \mathrm{~d}$ & $2.83 \mathrm{~b}$ & $8.7 \mathrm{a}$ & $0.62 \mathrm{a}$ & $9.84 \mathrm{~b}$ & $143.7 \mathrm{c}$ \\
\hline Lime $+\mathrm{NH}_{4} \mathrm{NO}_{3}$ & $4.55 \mathrm{c}$ & $2.72 \mathrm{c}$ & $4.66 \mathrm{~d}$ & $109.9 \mathrm{c}$ & $0.60 \mathrm{a}$ & $12.67 \mathrm{~d}$ & $128.2 \mathrm{a}$ \\
\hline SED & 0.09 & 0.41 & 0.39 & 7.05 & 0.04 & 0.15 & 2.20 \\
\hline \multicolumn{8}{|l|}{ Plant species } \\
\hline Unplanted soil & $4.50 \mathrm{~b}$ & $\mathrm{~N} / \mathrm{A}$ & N/A & $101.9 \mathrm{~b}$ & $0.61 \mathrm{~b}$ & $7.88 \mathrm{a}$ & $131.2 \mathrm{~b}$ \\
\hline A. capillaris & $4.13 \mathrm{a}$ & $0.79 \mathrm{a}$ & $0.84 \mathrm{a}$ & $38.3 \mathrm{a}$ & $0.48 \mathrm{a}$ & $11.96 \mathrm{~b}$ & $174.2 \mathrm{c}$ \\
\hline L. perenne & $4.48 \mathrm{~b}$ & $4.25 \mathrm{~b}$ & $5.73 \mathrm{~b}$ & $104.2 \mathrm{~b}$ & $0.70 c$ & $12.36 \mathrm{c}$ & $121.4 \mathrm{a}$ \\
\hline$P$-value & $* *$ & $* * *$ & $* * *$ & $* * *$ & $* * *$ & $* * *$ & $* * *$ \\
\hline SED & 0.09 & 0.49 & 0.48 & 11.47 & 0.04 & 0.13 & 2.85 \\
\hline
\end{tabular}

$\mathrm{pH}$, as ammonium is converted to nitrate (nitrification) [18]. Amendment with lime plus nitrogen raised $\mathrm{pH}$ to nearly the same level as lime alone, indicating that the neutralizing effect of lime overrode the acidifying effect of nitrogen. Plant species also altered $\mathrm{pH}$, with lowest $\mathrm{pH}$ recorded in A. capillaris pots. Plant biomass varied with chemical treatment, with $\mathrm{N}$ resulting in higher root biomass across plant treatments, while liming appeared to have the biggest effect on shoot biomass. Plant biomass was significantly different $(P<.001)$ depending on plant species, with $L$. perenne producing significantly greater $(P<.001)$, root, and shoot biomass compared to A. capillaris. Microbial activity decreased significantly under $\mathrm{N}$ treatment, whereas lime application (both lime alone, plus lime with $\mathrm{N}$ ) appeared to have a positive effect on microbial activity. Within plant treatments, a significant decrease $(P<.001)$ in microbial activity was noted in A. capillaris pots. Soil nitrogen (\%), phosphorus and potassium values are also presented in Table 1.

ANOSIM $R$-statistics are presented in Table 2. AOB community structure was significantly affected by both chemical treatment (global $R=0.684$ ) and plant species (global $R=0.584$ ), with significance level at $P<.005$. The larger $R$ values for chemical treatment indicated that treatment had a greater effect on $\mathrm{AOB}$ community structure than plant species type. PERMANOVA pairwise comparisons for $\mathrm{AOB}$ community structure showed significant effects $(P<.001)$ of all management treatments $(\mathrm{L}, \mathrm{N}, \mathrm{LN})$, plant species, and their interactions on $\mathrm{AOB}$ community structure. In order to elucidate the main drivers of $\mathrm{AOB}$ community structure, PCO ordinations (Figure 1) were derived and showed marked separation of samples depending on chemical treatment. For both unplanted and planted soils, there was a general grouping together of NT and L treatments, suggesting a high similarity within TRFLP profiles under NT and $\mathrm{L}$ treatments. Figure 1(a) indicated that for unplanted soils, the addition of $\mathrm{N}$ selected for markedly different
TABLE 2: ANOSIM R-statistics for pairwise comparisons of chemical treatments (lime, nitrogen, lime + nitrogen) and plant species (unplanted, A. capillaris, L. perenne) on ammonia-oxidising bacterial communities. NT, no treatment. All comparisons were significant $(P<.005)$.

\begin{tabular}{lc}
\hline Treatment/Plant groups & $R$-statistic \\
\hline NT, Lime & 0.382 \\
NT, Nitrogen & 0.819 \\
NT, Lime + Nitrogen & 0.708 \\
Lime, Nitrogen & 1 \\
Lime, Lime + Nitrogen & 0.852 \\
Nitrogen, Lime + Nitrogen & 0.535 \\
\hline Unplanted, A. capillaris & 0.568 \\
Unplanted, L. perenne & 0.477 \\
A. capillaris, L. perenne & 0.755 \\
\hline
\end{tabular}

AOB communities in comparison to NT and $\mathrm{L}$ treatments, while the $\mathrm{LN}$ interaction also resulted in a divergent $\mathrm{AOB}$ community, indicating a significant combined effect of $\mathrm{N}$ and $\mathrm{L}$ within these microcosms. Figure $1(\mathrm{~b})$ showed that in A. capillaris planted soils, although the NT and L treatments were grouped together and considerably separated from $\mathrm{N}$ and LN, there was no definite difference between $\mathrm{N}$ and $\mathrm{LN}$, as was seen in the unplanted pots. Figure 1(c) (L. perenne) followed a similar pattern to unplanted, with $\mathrm{N}$ and LN separating out from each other on the PCO ordination.

Figure 2 indicated broad treatment-driven shifts in $\mathrm{AOB}$ community structure, as determined from relative abundances of dominant AOB OTUs using the SIMPER procedure. The most abundant OTUs in N-treated microcosms were markedly different from NT and L pots, suggesting apparent selection for different $\mathrm{AOB}$ species depending on management factor. Interestingly, the four OTUs present in $\mathrm{N}$ treatment (Figure 2) were also present in LN treatment, 


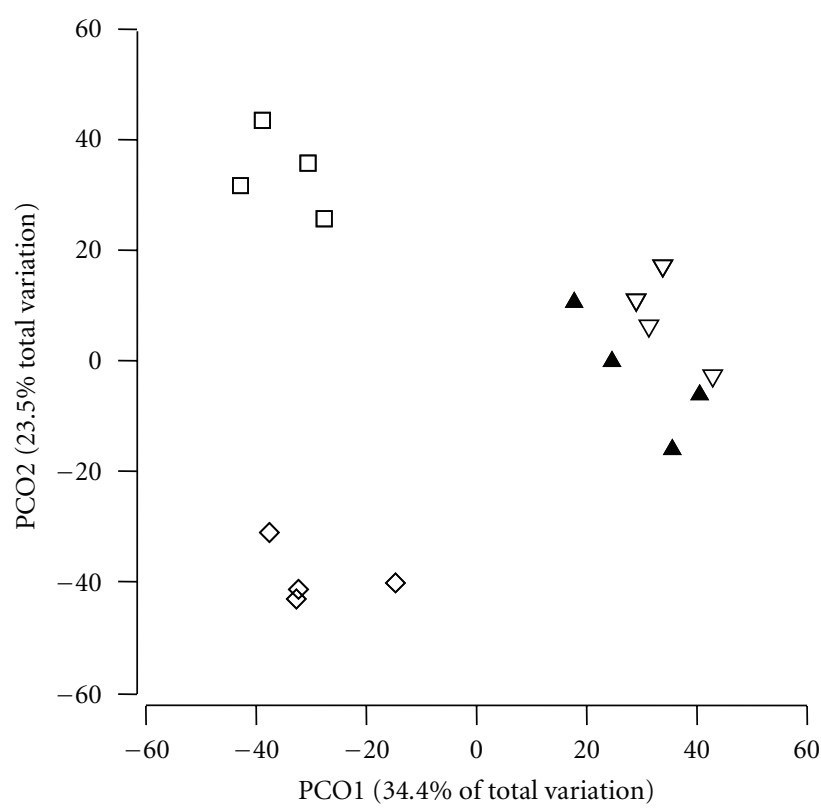

(a)

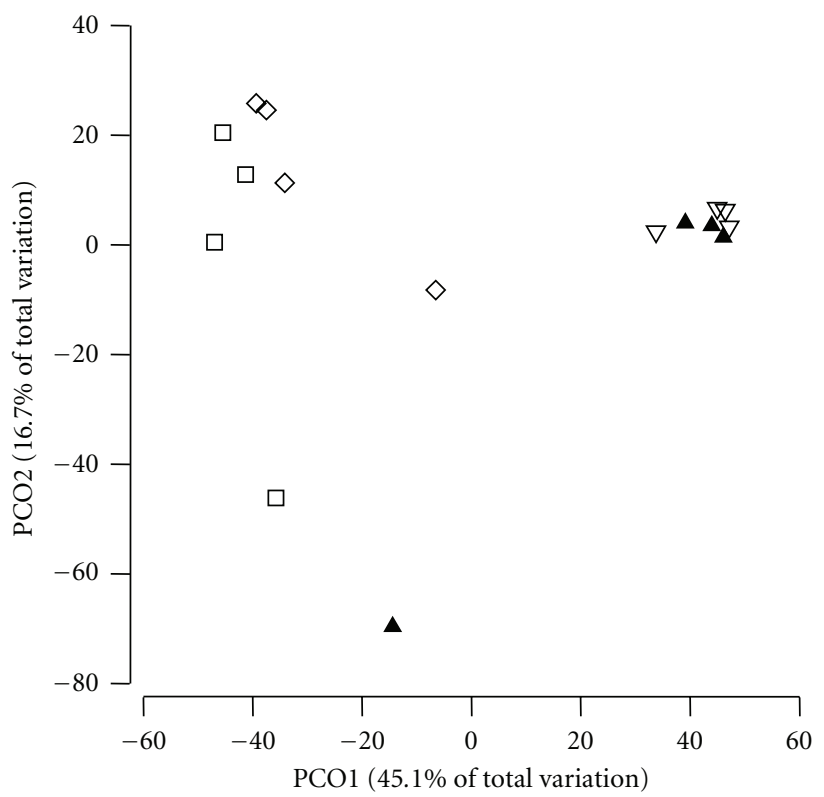

(b)

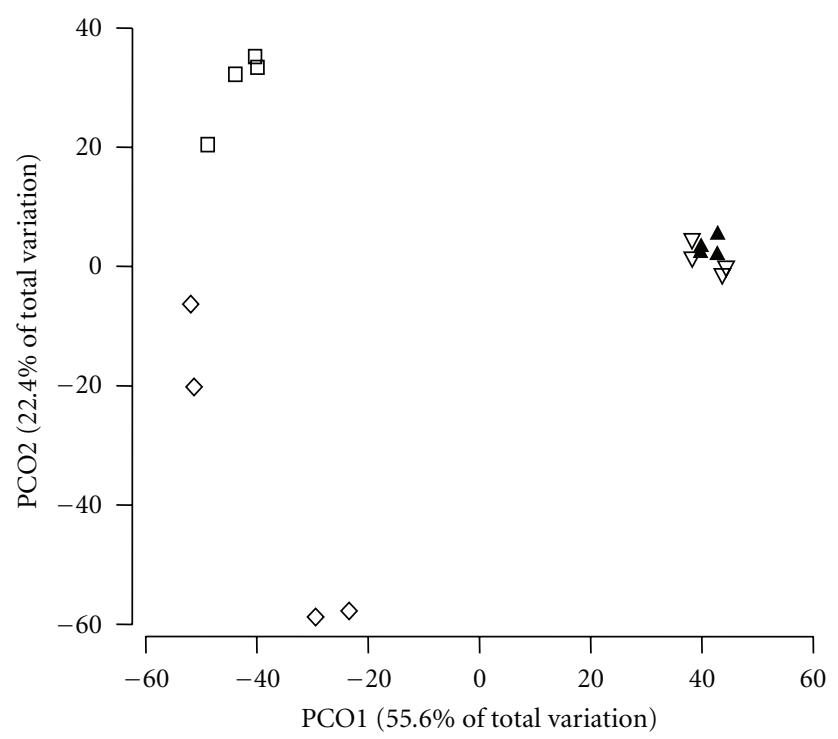

(c)

FIgURe 1: Principal coordinate analysis (PCO) plots of ammonia-oxidising bacterial community profiles examining management effects within each plant treatment. (a) unplanted soil, (b) A. capillaris, (c) L. perenne. Key: closed triangle, no treatment; inverted triangle, lime treatment; square, nitrogen treatment; and diamond, lime plus nitrogen treatment.

suggesting that $\mathrm{N}$ was very influential in determining $\mathrm{AOB}$ community structure. On the other hand, NT and $\mathrm{L}$ treatments were more similar in terms of AOB species composition. These data imply that $\mathrm{N}$ was dominant in driving AOB community structure. Table 3 gives the number of TRFs present under each treatment. Under NT, there was a slight but significant decrease in number of TRFs detected. There were no significant differences in number of TRFs between plant treatments in the L treated pots, while L, N, and LN treatments revealed some significant differences in TRF number. The most noticeable difference in number of
TRFs was in the $\mathrm{N}$ treatment and LN treatments, where a significant reduction in number of TRFs in A. capillaris and L. perenne pots, respectively, was found.

\section{Discussion}

The main finding of this study was that nitrogen addition to upland grassland soil significantly influenced AOB community structure, and that the response was also dependent on which plant species was present. It has been shown 
TABle 3: Number of ammonia oxidiser TRFs (amoA) detected under each treatment and plant species. Different letters represent significant differences within a treatment, $n=4$.

\begin{tabular}{lcccc}
\hline & No treatment & Lime & Nitrogen & Lime + Nitrogen \\
\hline Unplanted & $30 \mathrm{a}$ & $42 \mathrm{a}$ & $65 \mathrm{a}$ & $57 \mathrm{a}$ \\
A. capillaris & $30 \mathrm{a}$ & $49 \mathrm{a}$ & $3 \mathrm{c}$ & $49 \mathrm{a}$ \\
L. perenne & $20 \mathrm{~b}$ & $49 \mathrm{a}$ & $10 \mathrm{~b}$ & $29 \mathrm{~b}$ \\
\hline
\end{tabular}

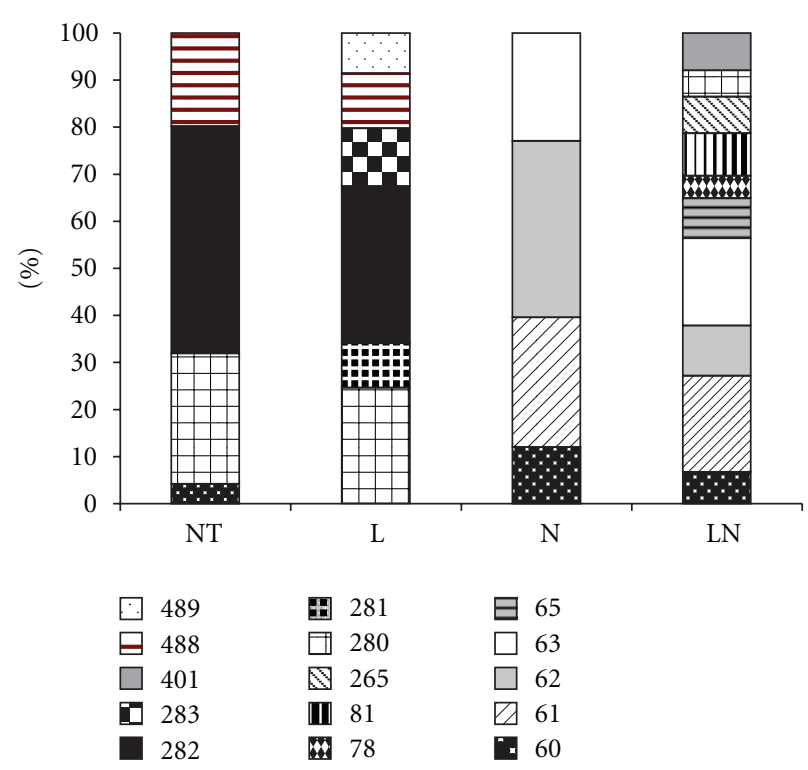

FIgURE 2: Relative percentage abundance of individual ammoniaoxidising bacterial OTUs occurring in the Top 10 most abundant OTUs within treatment. Top 10 most abundant OTUs were determined based on ranked relative abundances of OTUs within each treatment. No treatment (NT), lime (L), nitrogen $(\mathrm{N})$ and lime + nitrogen (LN) treatments. Abundances are illustrated according to the key at bottom, with the corresponding TRF length (bp) listed alongside.

previously that nitrogen manipulations can lead to shifts in $\mathrm{AOB}$ community structure $[19,20]$, but the simultaneous effects of different plant species on $\mathrm{AOB}$ community structure have not been characterised. The results of this study present evidence for floristic and chemical interactions in grasslands selecting for distinct $\mathrm{AOB}$ populations. The ability of key functional communities in soils to respond to environmental influences suggests that overall functioning, in this case nitrification may persist over a broad range of ecological conditions.

In terms of plant growth responses to nitrogen and lime treatments in this study, L. perenne accounted for the majority of variance seen in root and shoot biomass measurements $[6,7]$, probably due to fundamental differences in growth morphology and root architectures between the two key plant species. $L$. perenne responds positively to $\mathrm{N}$ inputs in soil and it has been suggested that the root system of $L$. perenne may be competitively advantageous over other plant species when high concentrations of soil $\mathrm{N}$ are present [21]. In addition, high inputs of fertiliser $\mathrm{N}$ are required to maintain the floristic characteristics of improved pastures, in which $L$. perenne dominates. The differences in the fundamental morphologies and physiologies of these two key plant species in response to nitrogen and lime manipulations, may result in concurrent shifts in rhizosphere microbial ecology, including $\mathrm{AOB}$ populations.

Liming of grasslands is routinely carried out during agricultural improvement, therefore, $\mathrm{AOB}$ community structure may also be influenced by lime-induced $\mathrm{pH}$ changes that are concurrent with improvement. Slightly higher soil $\mathrm{pH}$ induced by liming may favour certain microbial processes, hence, encouraging greater soil microbial activity. Figure 1 indicates that the presence of A. capillaris prevented the LN treatment from substantially altering $\mathrm{AOB}$ community structure in these microcosms, when compared to the unplanted control. Additionally, $\mathrm{AOB}$ populations under $\mathrm{N}$ and $\mathrm{LN}$ treatments on the A. capillaris ordination plot revealed similar AOB community composition. Interestingly, in both unplanted and L. perenne pots, $\mathrm{AOB}$ populations in $\mathrm{N}$ and LN treatments are markedly different, suggesting differential selection for $\mathrm{AOB}$ populations depending on interacting environmental factors. Several studies have indicated that selection for acid/alkaline tolerant AOB species may occur in natural environments in response to shifts in soil $\mathrm{pH}$ status [22-24]. As A. capillaris is known to have an acidifying effect on its rhizosphere [25], perhaps this phenomenon prevents lime from influencing soil $\mathrm{pH}$ in A. capillaris pots as compared to unplanted and L. perenne pots (Table 1 ). The results presented herein propose that liming and nitrogen applications to acidic grasslands may alter the structure of resident $\mathrm{AOB}$ populations, selecting for those that are better suited to the prevailing environmental conditions, such as variations in $\mathrm{N}$ availability (fertilised/unfertilised) or changes in $\mathrm{pH}$, either as a result of liming or via addition of $\mathrm{NH}_{4} \mathrm{NO}_{3}$, which can acidify soil. In unimproved acidic grasslands, where there is higher floristic and chemical diversity [11], soil heterogeneity could lead to greater grassland $\mathrm{AOB}$ diversity. $\mathrm{AOB}$ diversity has been shown to be lower in improved grasslands $[11,26]$, while greater $\mathrm{AOB}$ diversity in unimproved soils is likely to reflect natural physical and chemical heterogeneity, emphasising the importance of soil physicochemical parameters in the determination of microbial community structure and functioning in general.

For unplanted and planted (both A.capillaris and $L$. perenne) soils, there was a high similarity in TRFLP profiles under NT and L treatments (Figure 1), suggesting that lime application alone did not markedly change the $\mathrm{AOB}$ community structure in these microcosms. Conversely, $\mathrm{N}$ is proposed as a dominant factor governing $\mathrm{AOB}$ community structure in this study, which supports previous studies [19, 20, 27-29]. Mendum and Hirsch [19] further suggested that $\mathrm{NH}_{4} \mathrm{NO}_{3}$ application is specifically required for certain Nitrosospira clusters to become the dominant AOB population, perhaps indicating a substrate-driven selection for $\mathrm{AOB}$ populations, while Cavagnaro et al. [29] suggested that $\mathrm{AOB}$ in an agricultural soil was determined by $\mathrm{NH}_{4}{ }^{+}$availability, which selected for ammonia oxidizers that rapidly oxidise available $\mathrm{NH}_{4}{ }^{+}$. Additionally, in our study, $\mathrm{NH}_{4} \mathrm{NO}_{3}$ could alternatively have induced $\mathrm{AOB}$ populations to respond 
to a change in $\mathrm{pH}$, selecting for $\mathrm{AOB}$ populations that have adapted to more acidic conditions, as brought about by $\mathrm{NH}_{4} \mathrm{NO}_{3}$ fertilisation. This is further supported by Figure 2, which showed marked differences in AOB population structure under different treatments. Many recent studies on $\mathrm{AOB}$ communities have also found that $\mathrm{AOB}$ in terrestrial environments are more likely to be dominated by Nitrosospira species [30, 31], rather than Nitrosomonas. Extensive phylogenetic analyses of $B$-proteobacteria $\mathrm{AOB}$ from terrestrial environments have revealed the presence of a number of clusters within the AOB community, encompassing both Nitrosomonas and Nitrosospira genera $[22,32,33]$. It is possible that these phylogenetic clusters are a result of physiological differences in $\mathrm{AOB}$ populations that may allow certain populations to become dominant under different environmental conditions [20], but problems with culturing $\mathrm{AOB}$ make it difficult to prove this for certain.

While only two plant species were investigated in this study, natural acidic grasslands maintain a higher diversity of plant species, presenting a highly complex system in which it is difficult to generalise the effects of plant species. Additionally, the Crenarchaea have recently been revealed as important contributors to ammonia oxidisation in terrestrial systems [33]. Although crenarchaeal ammonia oxidation was not investigated as part of this study, it is likely that AOB is only partially responsible for regulating ammonia oxidation in grassland soils, so caution must be expressed when evaluating the importance of findings such as those presented in this study. Nevertheless, AOB community dynamics are an integral component of overall ammonia oxidation in soil.

\section{Conclusion}

In conclusion, this study has shown that nitrogen status and plant species type, plus their interactions, play major roles in the determination of $\mathrm{AOB}$ community structure in upland acidic pastures. While much valuable data have previously been presented on the responses of soil AOB communities to changes in soil $\mathrm{N}$ status (e.g., $[11,28,34-36]$ ), often studies do not consider the combined effects of plant species type an important component of agricultural improvement. The data presented herein suggest that individual plant species may affect $\mathrm{AOB}$ communities differently in response to fertiliser treatment, adding to the complexity of grassland microbial ecology. Future work should aim to link ammoniaoxidiser community dynamics with soil properties and functional processes, including those regulated by plants, to gain a more comprehensive insight into the factors regulating ammonia oxidiser structure and nitrification dynamics in agricultural systems.

\section{Acknowledgments}

This study was funded by the Environmental Protection Agency under the ERTDI scholarship scheme (2003). The authors thank Mary Murphy and Maria Benson for technical assistance.

\section{References}

[1] T. H. Blackstock, C. A. Rimes, D. P. Stevens et al., "The extent of semi-natural grassland communities in lowland England and Wales: a review of conservation surveys 1978-1996," Grass and Forage Science, vol. 54, no. 1, pp. 1-18, 1999.

[2] B. H. Green, "Agricultural intensification and the loss of habitat, species and amenity in British grasslands, a review of historical change and assessment of future prospects," Grass and Forage Science, vol. 45, pp. 365-372, 1990.

[3] J. S. Rodwell, British Plant Communities, Grasslands and Montane Communities, Cambridge University Press, Cambridge, UK, 1992.

[4] R. D. Bardgett, J. L. Mawdsley, S. Edwards, P. J. Hobbs, J. S. Rodwell, and W. J. Davies, "Plant species and nitrogen effects on soil biological properties of temperate upland grasslands," Functional Ecology, vol. 13, no. 5, pp. 650-660, 1999.

[5] E. Brodie, S. Edwards, and N. Clipson, "Bacterial community dynamics across a floristic gradient in a temperate upland grassland ecosystem," Microbial Ecology, vol. 44, no. 3, pp. 260-270, 2002.

[6] N. Kennedy, E. Brodie, J. Connolly, and N. Clipson, "Impact of lime, nitrogen and plant species on bacterial community structure in grassland microcosms," Environmental Microbiology, vol. 6, no. 10, pp. 1070-1080, 2004.

[7] N. Kennedy, J. Connolly, and N. Clipson, "Impact of lime, nitrogen and plant species on fungal community structure in grassland microcosms," Environmental Microbiology, vol. 7, no. 6, pp. 780-788, 2005.

[8] J. I. Prosser and T. M. Embley, "Cultivation-based and molecular approaches to characterisation of terrestrial and aquatic nitrifiers," Antonie van Leeuwenhoek, vol. 81, no. 1-4, pp. 165-179, 2002.

[9] C. J. Phillips, E. A. Paul, and J. I. Prosser, "Quantitative analysis of ammonia oxidising bacteria using competitive PCR," FEMS Microbiology Ecology, vol. 32, no. 2, pp. 167-175, 2000.

[10] A. M. Ibekwe, A. C. Kennedy, P. S. Frohne, S. K. Papiernik, C.-H. Yang, and D. E. Crowley, "Microbial diversity along a transect of agronomic zones," FEMS Microbiology Ecology, vol. 39, no. 3, pp. 183-191, 2002.

[11] G. Webster, T. M. Embley, and J. I. Prosser, "Grassland management regimens reduce small-scale heterogeneity and species diversity of $\beta$-proteobacterial ammonia oxidizer populations," Applied and Environmental Microbiology, vol. 68, no. 1, pp. 20-30, 2002.

[12] K. Alef and P. Nannipieri, Methods in Applied Soil Microbiology and Biochemistry, Academic Press, London, UK, 1995.

[13] A. Thalmann, "Zur methodik ber Bestimmung der dehydrogenaseaktivität im Boden mittels triphenyltetrazoliumchlorid (TTC)," Landwirtsch Forsch, vol. 21, pp. 249-258, 1968.

[14] J.-H. Rotthauwe, K.-P. Witzel, and W. Liesack, "The ammonia monooxygenase structural gene amoa as a functional marker: molecular fine-scale analysis of natural ammonia-oxidizing populations," Applied and Environmental Microbiology, vol. 63, no. 12, pp. 4704-4712, 1997.

[15] H.-P. Horz, J.-H. Rotthauwe, T. Lukow, and W. Liesack, "Identification of major subgroups of ammonia-oxidizing bacteria in environmental samples by T-RFLP analysis of amoA PCR products," Journal of Microbiological Methods, vol. 39, no. 3, pp. 197-204, 2000.

[16] J. Dunbar, L. O. Ticknor, and C. R. Kuske, "Phylogenetic specificity and reproducibility and new method for analysis 
of terminal restriction fragment profiles of 16S rRNA genes from bacterial communities," Applied and Environmental Microbiology, vol. 67, no. 1, pp. 190-197, 2001.

[17] K. R. Clarke, "Non-parametric multivariate analyses of changes in community structure," Australian Journal of Ecology, vol. 18, no. 1, pp. 117-143, 1993.

[18] G. Fenton and K. R. Helyar, "Soil acidification," in Soils: Their Properties and Management, P. E. Charman and B. W. Murphy, Eds., pp. 221-245, Oxford University Press, Victoria, Australia, 2000.

[19] T. A. Mendum and P. R. Hirsch, "Changes in the population structure of $\beta$-group autotrophic ammonia oxidising bacteria in arable soils in response to agricultural practice," Soil Biology and Biochemistry, vol. 34, no. 10, pp. 1479-1485, 2002.

[20] G. Webster, T. M. Embley, T. E. Freitag, Z. Smith, and J. I. Prosser, "Links between ammonia oxidizer species composition, functional diversity and nitrification kinetics in grassland soils," Environmental Microbiology, vol. 7, no. 5, pp. 676-684, 2005.

[21] E. Personeni, A. Lüscher, and P. Loiseau, "Rhizosphere activity, grass species and $\mathrm{N}$ availability effects on the soil $\mathrm{C}$ and $\mathrm{N}$ cycles," Soil Biology and Biochemistry, vol. 37, no. 5, pp. 819827, 2005.

[22] J. R. Stephen, A. E. McCaig, Z. Smith, J. I. Prosser, and T. M. Embley, "Molecular diversity of soil and marine 16S rRNA gene sequences related to $\beta$-subgroup ammonia-oxidizing bacteria," Applied and Environmental Microbiology, vol. 62, no. 11, pp. 4147-4154, 1996.

[23] G. A. Kowalchuk, J. R. Stephen, W. de Boer, J. I. Prosser, T. M. Embley, and J. W. Woldendorp, "Analysis of ammoniaoxidizing bacteria of the $\beta$ subdivision of the class proteobacteria in coastal sand dunes by denaturing gradient gel electrophoresis and sequencing of PCR-amplified 16S ribosomal DNA fragments," Applied and Environmental Microbiology, vol. 63, no. 4, pp. 1489-1497, 1997.

[24] J. M. Regan, G. W. Harrington, and D. R. Noguera, "Ammonia- and nitrite-oxidizing bacterial communities in a pilot-scale chloraminated drinking water distribution system," Applied and Environmental Microbiology, vol. 68, no. 1, pp. 7381, 2002.

[25] J. P. Grime, "Benefits of plant diversity to ecosystems: immediate, filter and founder effects," Journal of Ecology, vol. 86, no. 6, pp. 902-910, 1998.

[26] M. A. Bruns, J. R. Stephen, G. A. Kowalchuk, J. I. Prosser, and E. A. Paul, "Comparative diversity of ammonia oxidizer $16 \mathrm{~S}$ rRNA gene sequences in native, tilled, and successional soils," Applied and Environmental Microbiology, vol. 65, no. 7, pp. 2994-3000, 1999.

[27] G. A. Kowalchuk, A. W. Stienstra, G. H. J. Heilig, J. R. Stephen, and J. W. Woldendorp, "Molecular analysis of ammoniaoxidising bacteria in soil of successional grasslands of the Drentsche A (The Netherlands)," FEMS Microbiology Ecology, vol. 31, no. 3, pp. 207-215, 2000.

[28] S. Avrahami, W. Liesack, and R. Conrad, "Effects of temperature and fertilizer on activity and community structure of soil ammonia oxidizers," Environmental Microbiology, vol. 5, no. 8, pp. 691-705, 2003.

[29] T. R. Cavagnaro, L. E. Jackson, K. Hristova, and K. M. Scow, "Short-term population dynamics of ammonia oxidizing bacteria in an agricultural soil," Applied Soil Ecology, vol. 40, no. 1, pp. 13-18, 2008.
[30] J. S. K. Bäckman, A. Hermansson, C. C. Tebbe, and P.-E. Lindgren, "Liming induces growth of a diverse flora of ammoniaoxidising bacteria in acid spruce forest soil as determined by SSCP and DGGE," Soil Biology and Biochemistry, vol. 35, no. 10, pp. 1337-1347, 2003.

[31] S. Mahmood and J. I. Prosser, "The influence of synthetic sheep urine on ammonia oxidizing bacterial communities in grassland soil," FEMS Microbiology Ecology, vol. 56, no. 3, pp. 444-454, 2006.

[32] J. R. Stephen, G. A. Kowalchuk, M.-A. V. Bruns et al., "Analysis of $\beta$-subgroup proteobacterial ammonia oxidizer populations in soil by denaturing gradient gel electrophoresis analysis and hierarchical phylogenetic probing," Applied and Environmental Microbiology, vol. 64, no. 8, pp. 2958-2965, 1998.

[33] S. Leininger, T. Urich, M. Schloter et al., "Archaea predominate among ammonia-oxidizing prokaryotes in soils," Nature, vol. 442, no. 7104, pp. 806-809, 2006.

[34] S. Avrahami and B. J. M. Bohannan, " $\mathrm{N}_{2} \mathrm{O}$ emission rates in a California meadow soil are influenced by fertilizer level, soil moisture and the community structure of ammonia-oxidizing bacteria," Global Change Biology, vol. 15, no. 3, pp. 643-655, 2009.

[35] J. J. L. Cantera, F. L. Jordan, and L. Y. Stein, "Effects of irrigation sources on ammonia-oxidizing bacterial communities in a managed turf-covered aridisol," Biology and Fertility of Soils, vol. 43, no. 2, pp. 247-255, 2006.

[36] K. Nyberg, A. Schnürer, I. Sundh, Å. Jarvis, and S. Hallin, "Ammonia-oxidizing communities in agricultural soil incubated with organic waste residues," Biology and Fertility of Soils, vol. 42, no. 4, pp. 315-323, 2006. 

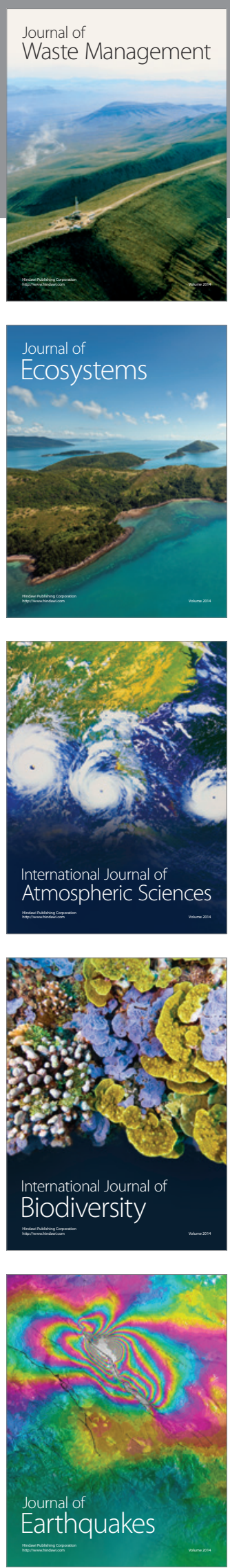
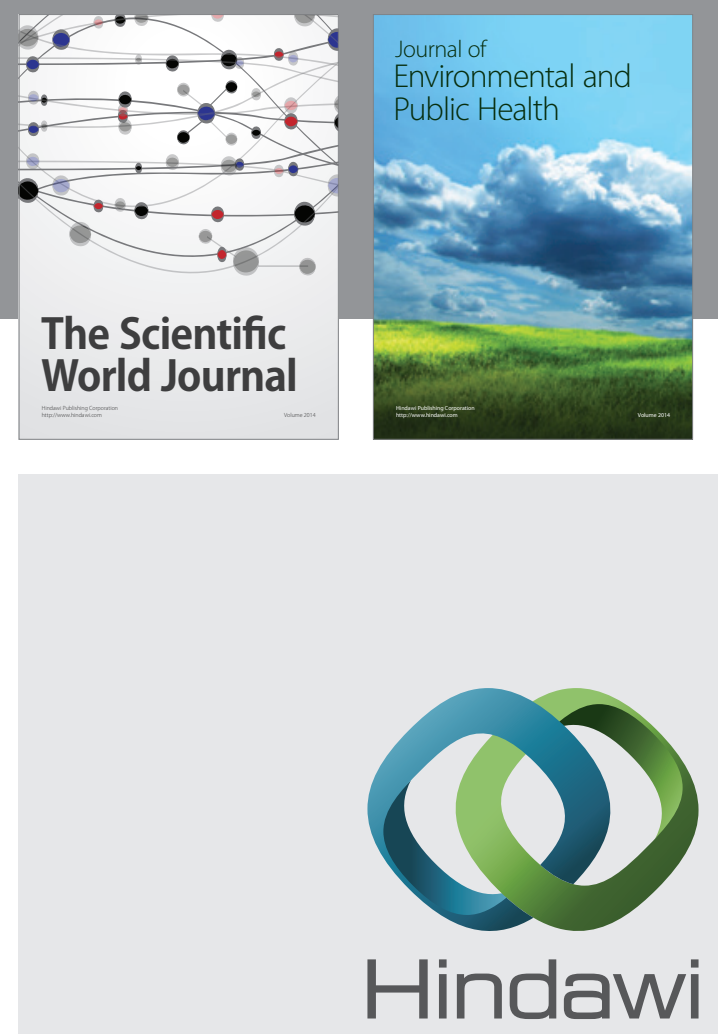

Submit your manuscripts at

http://www.hindawi.com
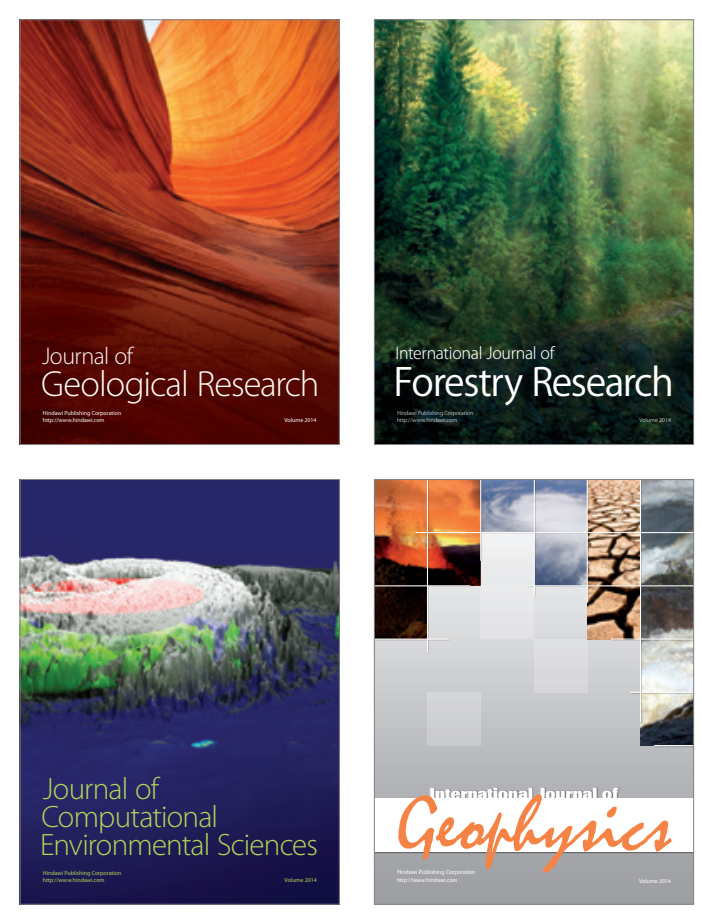
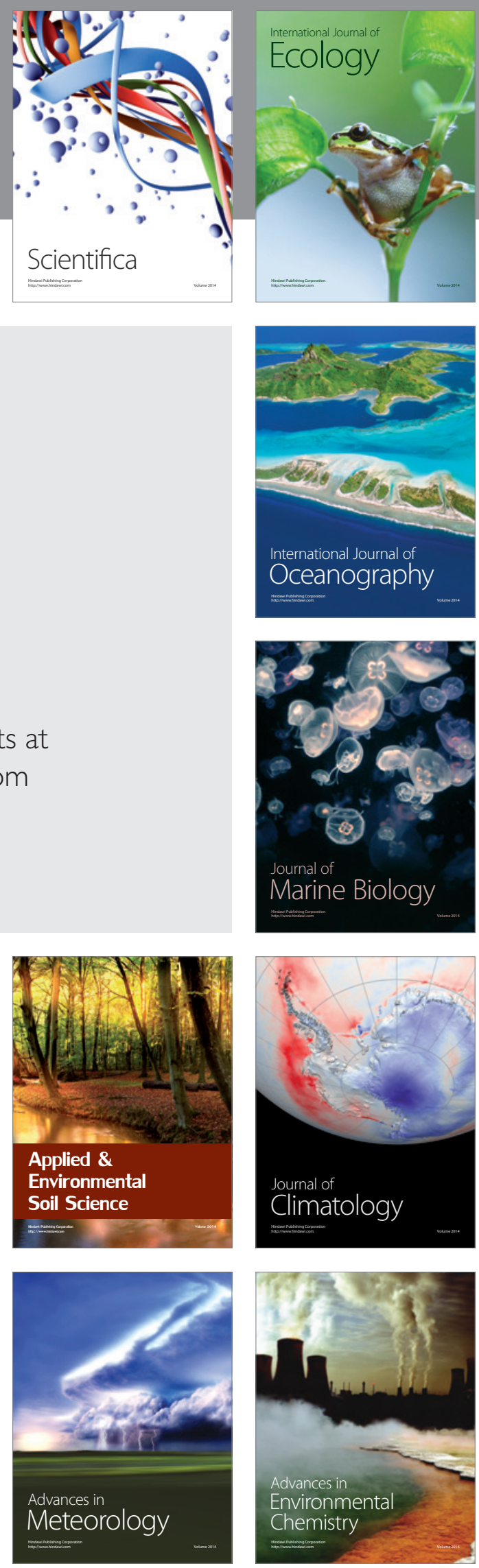